\title{
E-Business and E-Commerce: The structure of the new commerce world and how Ghanaians are seriously equipping themselves and poised to be included in this modern and global business transaction.
}

\author{
Dr. Francis Kwadade-Cudjoe \\ FBCS, FIMIS, PhD, MBA, BSc (Hons) \\ Senior Lecturer, Knutsford University College and Adjunct Lecturer, \\ GIMPA Business School, Accra, Ghana.
}

\begin{abstract}
E-Business and E-Commerce are currently the vogue in transacting business globally. The mode of transacting business with this modern approach is so simple that, it is likely a huge number of the global population are already there. Ghana, an emerging market in Africa and the globe, has the attractiveness to join this craze. The current government has been able to eliminate the quack financial institutions from the banking system, and technologically established and launched the infrastructure for Ghana's Interbank Payment and Settlement Systems (GhIPSS). This is an internet payment gateway to enable holders of domestic Automated Teller Machine (ATM) cards to make payments and purchases online. Most of the Banks in Ghana have also come out with perks to customers who would adopt the online purchasing approach, and even use their ATM cards for their transactions. The enticement is seriously catching on, and there is the hope that the citizenry would listen to the advice of the government for all to join the digital transformation currently going on in Ghana.
\end{abstract}

Key words: E-Business, E-Commerce, internet, technology, emerging market, interbank payment \& settlement system, internet payment gateway and ATM.

\section{INTRODUCTION}

E-Commerce has been the current technological means of conducting business globally, and was started in 1995 when Netscape.com explored the idea of using the world-wide-web for sales and advertising, leading to growth in e-commerce for retail sales. Soon, sales revenue doubled and tripled, and mobile phones were also introduced for buying goods / services (Laudon \& Laudon, 2007) cited in (Al-Rawi, Sabry, \& Al-Nakeeb, 2008). Since then, there has been a steady rise in the use of e-commerce globally, by organisations to promote their businesses.

According to Lin (2007) cited in Al-Rawi et al. (2008), e-commerce has been associated with the need for change through emerging technologies to re-engineer the way in which business is conducted, improving process efficiency, flexibility, etc. to cater for the needs / expectations of customers. Furthermore, e-commerce enables organisations to expand to unknown frontiers, especially Small \& Medium-Sized Enterprises (SME) - (Al-Rawi et al. 2008), and, subsequently, leading to selecting the best suppliers from different geographical locations which enlarges the scope of global service market (Soopramanien et al., 2007) cited in (Al-Rawi et al., 2008).

E-Commerce may be defined as sharing of business information, maintaining business relationships, and conducting business transactions using digital networks (Zwass, 2003) cited in (Wu \& Hisa, 2008). E-Commerce could also be explained based on four (4) perspectives (Kalakota \& Whinston, 1997) cited in (Ngai \& Wat, 2002). These are: 
i. Communications perspective - It is the delivery of information, products / services, or payments via telephone lines, computer networks, or any other means.

ii. Business process perspective - It is the application of technology toward the automation of business transactions and workflow.

iii. Service perspective - It is a tool that addresses the desire of firms, consumers, and management to cut service costs while improving the quality of goods / services and increasing the speed of service delivery.

iv. Online perspective - It provides the capability of buying and selling products / services and information on the internet and other online systems (Kalakota \& Whinston, 1997) cited in (Ngai \& Wat, 2002).

E-Business on a wider scale, is the organisation that carries out e-commerce; therefore, firms that have embraced these e-commerce technologies are called electronic businesses (ebusinesses). They execute transactions, communicate, and innovate to support commerce through cyberspace (Wu \& Hisa, 2008). This may imply that e-commerce is an activity within an e-business, and its duty is to carry out the activities / perspectives enumerated above. ECommerce may therefore, be conveniently referred to as a Department within an e-business enterprise.

\section{Traditional commerce approach}

Traditionally, business has been carried out in the marketplace, where physical goods and services are exchanged via face-to-face human interaction, and / or in a physical location, popularly called shop, supermarket or store. For a transaction within a shop / supermarket or store, there has to be an attendant(s) who is to manage and supervise the purchase, and finally collect the physical cash paid out by the customer.

The traditional method of transacting business has also been known as the brick-and-mortar approach (Merriam-Webster, 2020), where a vendor acquires a shop and physically sells products to consumers.Traditional business transaction has been popular, and spread within the rural setting and a few of them within the urban location, as most business transactions within the urban locale take place through an e-commerce site, which operates through the internet.

\section{Modern commerce approach}

E-Business and E-Commerce are currently the most popular method of transacting business within the global market. This approach is quite different from the traditional method of trading, which used to be popular in the past years.

E-Commerce (electronic commerce), as we know it today, such as internet and mobile-enabled commerce (I- and $\mathrm{M}-$ ), is based on developments pertaining to the internet, and on prior technological innovations arising from the combination of telecommunication (ICT) and organizational computing (IT) - (Katzenbach \& Smith, 2001).

E-Commerce is the latest commercial business in vogue, and connoisseurs are not definite about its definition. However, what has been circulating as a fitting definition is, sharing of business information among partners, maintaining business relationships, and buying and selling products / services and information through digital networks or other online systems (Zwass, 2003) cited in (Wu \& Hisa, 2008), as stated above. 
Globally, the process of e-commerce begins when a buyer / consumer selects items of his / her choice online into a shopping basket / cart from an e-commerce site, and then pays for the cost of the items with a debit or credit card. Depending on the days chosen by the buyer to receive his / her products, based on the vendor's site, the same items purchased are despatched by the e-business to the buyer.

\section{CLASSIFICATION OF E-COMMERCE}

According to literature, e-commerce may be classified broadly into four main groups (Ngai \& Wat, 2002). These are:

a. applications - e-commerce functions that deal with technology, using application of systems to carry out activities / processes to achieve organizational desired goals. Examples are inter / intra-organisational systems (IOS) - known as extranet / intranet respectively, electronic payment systems (EPS), and education and training.

i. An inter-organizational system (IOS) is a unified system involving several business partners. Typically, they employ electronic data interchange (EDI), extranets (or internet), electronic funds transfer (EFT) and computer-based supply chain management systems.

ii. An intra-organizational system (IOS) deals with helping a company to maintain and support internal business processes between individuals, departments and collaborating organisations. The intranet is the popular internal network that links organisational employees by means of internet technology.

iii. An electronic payment system is used for online financial exchange between buyers and sellers. This exchange is usually in some form of digital financial instrument, such as e-cash, smart cards, credit / debit cards, and electronic cheques.

iv. Education and training cover published literature on education or training pertaining to on-line education, distance learning and virtual classrooms. The educational instruction is delivered electronically (Ngai \& Wat, 2002).

b. technological issues - the technology within the e-commerce system carries out various activities to preserve and secure users' data, and prevent malfunctioning of machines. Examples are Security and technological components.

i. Security consists of issues related to the protection of data and systems from errors. Common examples are encryption methods, such as private or public key cryptography normally done to secure user's data. Moreover, secure sockets layer (SSL) and cookies are other popular technologies available to help protect privacy and security online. Individual security can include passwords or digital signatures. In addition, firewalls and virtual private networking can ensure system security for protecting network systems against external and internal attacks, such as hackers.

ii. Technological components consist of various internet technologies, example, the common object request broker architecture (CORBA), software agents, mobile agents, bidding and negotiation which are distributed object management and agent software, which helps users in solving business problems. In addition, mark-up languages, such as standard generalized mark-up language (SGML), hypertext mark-up language (HTML), extensible mark-up language (XML) and programming languages like JAVA are the common web software developmental tools (Ngai \& Wat, 2002).

c. support and implementation - these are documented activities in the form of guidelines, processes, policies and strategies that govern and protect the activities / interest of stakeholders within an entity. Stakeholders include, among others, employees, consumers and investors. 
This classification is mainly divided into two broad categories:

i. public policy, and

ii. corporate strategy.

i. Public policy deals with what is expected from an organisation to conduct its business appropriately. Instances are Taxation, Privacy, Fraud and Trust.

- Taxation - The taxation of commerce conducted over the internet should be consistent with the established international principles. Avoidance of inconsistent national tax jurisdictions or double taxation should make it simple to administer and easy to understand. However, e-commerce may create difficult problems for applying existing tax schemes to its activities, as it is complicated by its decentralized nature.

- Privacy - data-gatherers should inform consumers what information they are collecting and how they intend to use it. Many people are concerned with privacy, because personal information may be gathered and re-used without authorization, as has been happening globally, and recently in Ghana, e.g. where people film activities with others, and without their consent publish them online.

- Fraud - deceptive practices exist in e-commerce. It is one of the most important issues that concern consumers. For example, whether an online company really exists to conduct business.

- Trust - this refers to positive expectation that is shown in the consistency and assurance between what a trading partner says and actually does.

ii. Corporate strategy deals with e-commerce plans and methodologies used in the building of successful corporate image and implementation plans for the organisation. Implementation plans include Strategic, Tactical and Operational activities.

. Strategic - long term plans of the organisation, normally beyond four (4) years.

. Tactical - medium term plans, normally between two (2) and four (4) years.

. Operational - daily plans of the organisation (Ngai \& Wat, 2002).

d. others - other aspects of e-commerce, such as general introduction, foundational concepts and adult stuffs of e-commerce (Ngai \& Wat, 2002).

A diagram of the classification or categories of e-commerce is given below, fig. a: 
Fig. a: Classification or categories of Electronic-Commerce

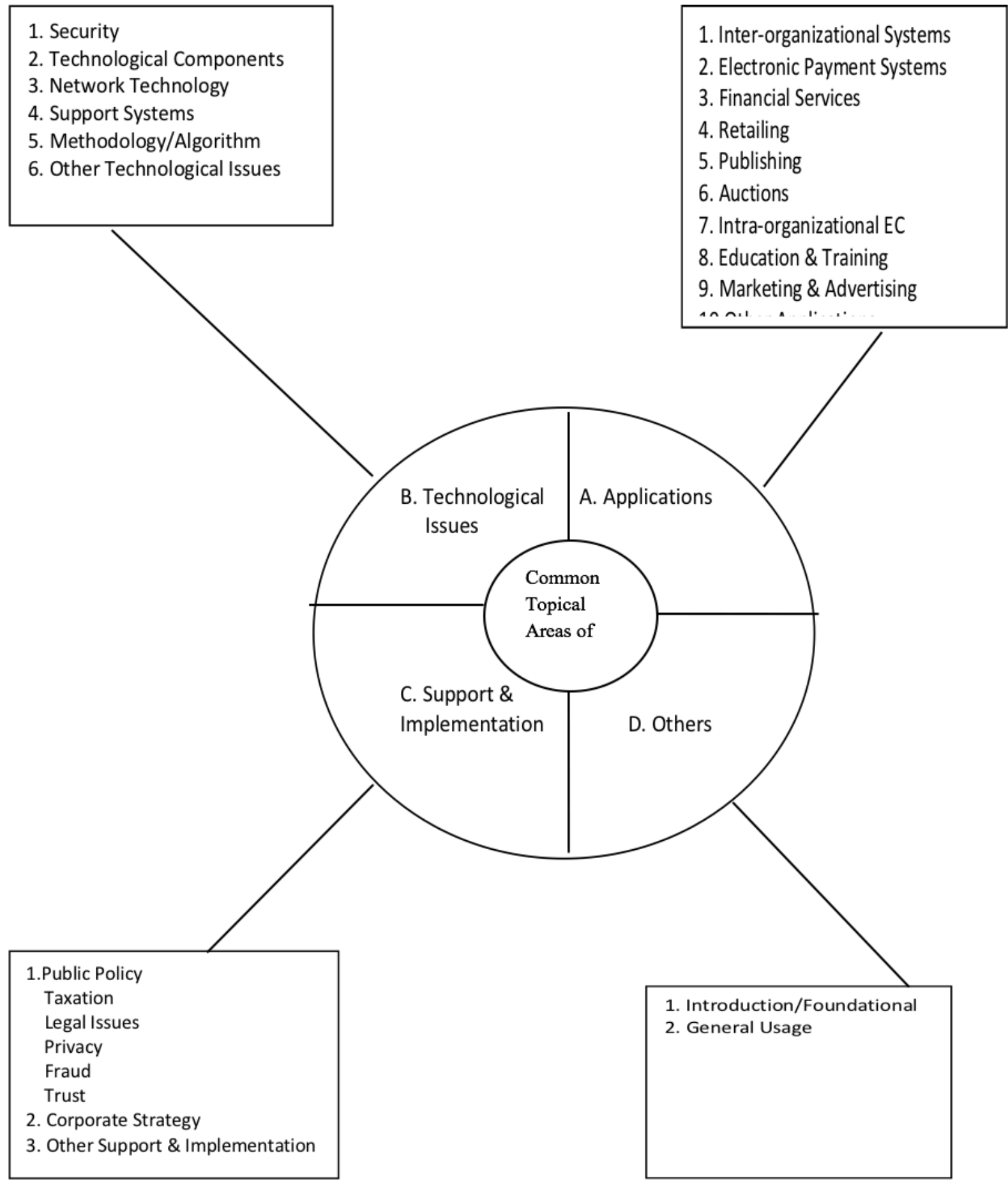

Source: Ngai, E. W. T. \& Wat, F. K. T. (2002). Information \& Management Journal.

\section{STRATEGIES OF E-COMMERCE}

There are many strategies associated with e-commerce and e-business. However, the four (4) Main strategies are:

a. Business-to-Business (B2B)

b. Business-to-Consumer (B2C)

c. Consumer-to-Consumer (C2C), and

d. Consumer-to-Business (C2B) - (Wu \& Hisa, 2008).

a. Business-to-Business (B2B) e-commerce is geared toward process-centric and even service-based information exchange. B2B e-commerce can provide collaborative 
business processes of an enterprise and business service level agreements and serviceoriented architectures. These architectures can lead to more flexibility, lower market entry costs, and integration of business modelling with process modelling (Hom, 2013). Traditional B2B e-commerce follows a document-centric approach, requiring electronic data interchange (EDI) and standardization of business document types for communication over special networks. However, process-centric B2B approaches focus on business information flow among business partners to eliminate redundancy in transmitted information (Hom, 2013; Clarity-Ventures, 2020).

b. Business-to-Consumer (B2C) e-commerce is a socio-technical system used not only to advertise products and services on the internet, but also to sell and share business information and products. The growth of business-to-consumer (B2C) e-commerce has gained a lot of attention among SMEs. Most B2C firms are turning their attention on how to retain new customers, which put them in a situation to compete with larger firms.

Fortunately for the SMEs, the social aspect of the transaction is important to some customers who learn about the organisation and its activities through browsing, and moreover, become familiar with the organisation (Ratnasingam, 2008; Hom, 2013).

c. Consumer-to-Consumer (C2C) is the business model that facilitates commerce between private individuals. This strategy connects people to do business with one another, either for goods and / or services, mainly through advertising. In this case, a consumer, but not a business, sells goods or services to another consumer, mainly facilitated by a third-party site that helps take care of the details of the transaction, usually referred to as a marketplace (Hom, 2013).

d. Consumer-to-Business (C2B) is a business model in which consumers create value, and businesses consume that value. For example, when a consumer writes reviews and businesses use them, gives a useful idea for new product development and businesses adopts them, participate in focus groups which brings out useful ideas for consumption by businesses, and influences what his / her audience buys (Hom, 2013; Hendricks, 2020).

\section{THE INTERNET BUSINESS MODEL (IBM)}

The organisational technologies have become a dynamic force that changes all types of business operations, leading to the organisational applications of these novel technologies causing a significant wave of e-commerce innovations. In the past two (2) decades, the emergence of the internet as a means for Internet-commerce (I-Commerce) was witnessed. In the I-commerce world, the traditional marketplace in which physical goods and services are exchanged via face-to-face human interaction, was supplemented or replaced by the virtual market-place that enabled the exchange of goods and services through the internet (Rayport \& Sviokla, 1994) cited in (Wu \& Hisa, 2008).

This change led to a radical overhaul of existing ways of doing business for brick-and-mortar firms. The I-commerce world soon became inadequate for business transactions, as the system matured into mobility, which I-commerce could not offer.

Today, wireless technology, i.e. Mobile-Commerce (M-commerce), is emerging even faster, producing significant advances that enabled the next generation after the I-commerce $(\mathrm{Wu} \&$ Hisa, 2008).

M-commerce refers to any transactions with mobile technology, and conducted over a wireless telecommunication network. The linkage between wireless devices and the internet has enormous potential to increase the overall volume of I-commerce. It also creates an 
unparalleled opportunity for e-business to leverage the benefits of mobility. M-commerce will pressure current e-businesses, engender a stream of changes among established e-commerce paradigms, which would lead to business model reconfiguration (Wu \& Hisa, 2008).

Ubiquitous (or universal) computing is being triggered by dramatic developments in wireless IT, continued chip and embedded device miniaturization, and new software service models. With this progress in Information Technology, a new breed of e-commerce that scholars call Ucommerce is developing in which the $u$ stands for ubiquity and universality. Ubiquity means that systems can support a rich set of computing and communication capabilities and services for travellers as they move in a transparent, integrated, convenient, and adaptive manner. Universality means that these systems provide a universal service channel that enables users to stay connected anywhere, anytime and using any device (Wu \& Hisa, 2008).

Consequently, U-commerce is a dynamic convergence of physical, digital, and traditional commerce with ubiquitous computing technologies to support personalized, uninterrupted communications and transactions. U-commerce will usher a new business world that presents an alternative view of space and time in a form that goes over, above, and beyond traditional commerce. The age of U-commerce will emerge soon. Predictably, the challenge of U-commerce will substantially change the business and marketing landscape and lead us to rethink many fundamental aspects of e-business operations, business models, and capabilities (Wu \& Hisa, 2008).

The various stages of the Internet Business Model (IBM) is shown below, fig. b, with S-curves of the I- M- \& U-commerce depicting the evolution of e-commerce innovations.

Fig. b: S Curves of E-Commerce innovation from I-, M-, to U-Commerce.

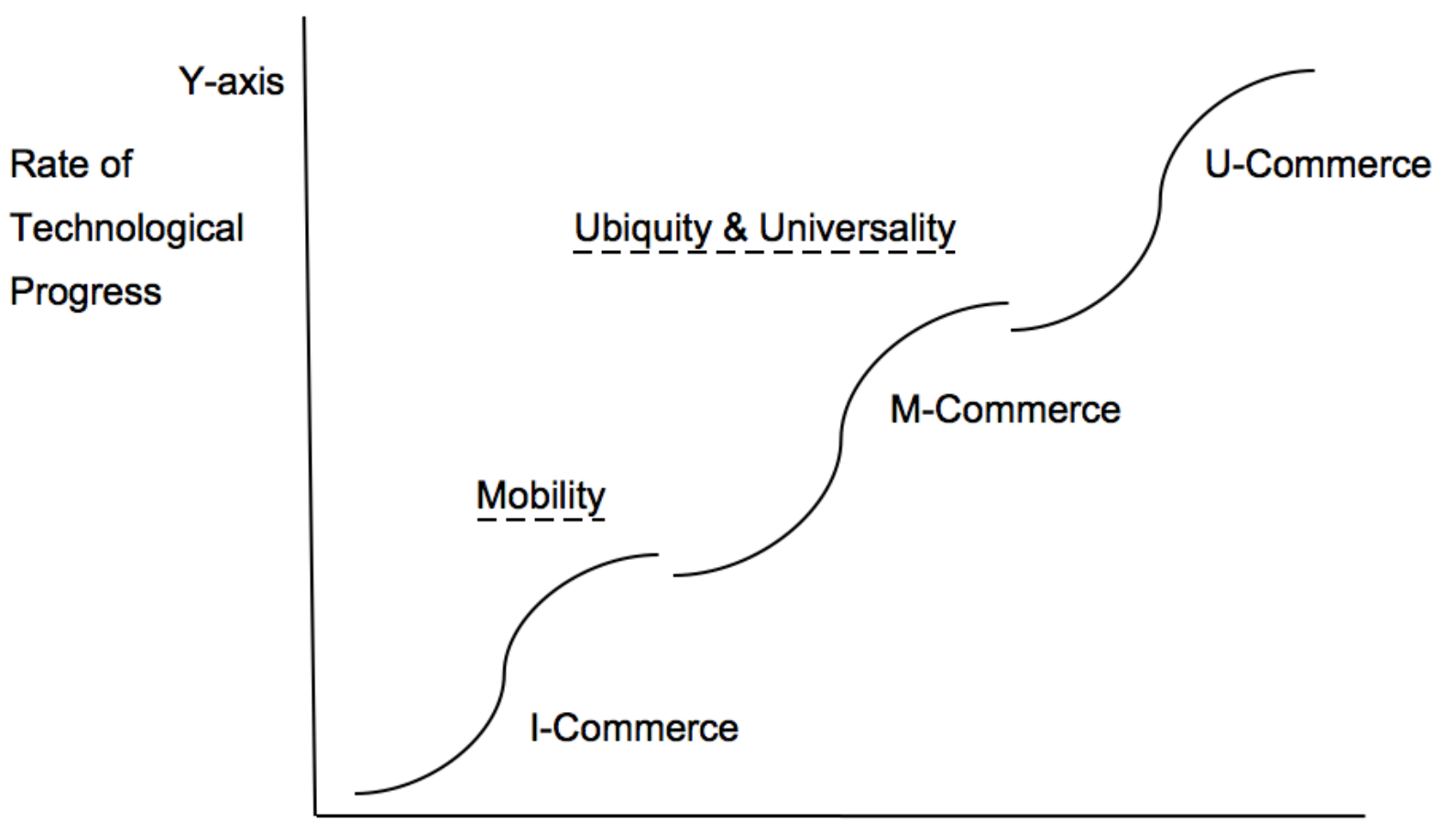

Time / Effort

X-axis

Source: Wu, J. H., \& Hisa, T. L. (2008). Journal of Organizational Computing and Electronic Commerce. 


\section{SOME E-COMMERCE SITES IN GHANA}

Ghanaians are privileged to have e-commerce sites, where they transact business online, with the use of the internet. Activities of some e-business sites would be provided to indicate the level of e-commerce activities / processes in Ghana, as provided by Anang (2015).

i. Tonaton.com is a website where you can buy and sell almost everything. The best deals are often done with people who live in your own city or on your own street, so on Tonaton.com it is easy to buy and sell locally (Anang, 2015). All you have to do is select your region. It is completely free, as opined by Anang (2015), to publish a classified advert on Tonaton.com, and it takes less than 2 minutes. You can sign up for a free account and post adverts easily any time. Tonaton.com has the widest selection of popular second hand items all over Ghana, which makes it easy to find exactly what you are looking for. So if you're looking for a car, mobile phone, house, computer system or even a pet, you will find the best deal on Tonaton.com. Tonaton.com does not specialize in any specific category, as at this site, one can buy and sell items in more than 50 different categories (Anang, 2015). However, Tonaton.com is an enabler, or organisation that creates the environment for the establishment of shops where buying and selling of items online are conducted. Unfortunately, transactions conducted within the environment of Tonaton.com are through the use of physical cash, which is not as envisaged, within an e-business environment.

ii. Carmudi.com.gh allows you to find the vehicle of your dreams. The aim of the website is to strengthen the position of consumers by providing information on the car market, and then the contact of individuals and professional sellers (Anang, 2015). Carmudi.com.gh strives to ensure that every advert provides the accurate information on each vehicle to make a consumer's choice easy.

The role of Carmudi.com.gh is to help find the right car and make the link with the owner. Carmudi.com.gh is a member of the family Rocket internet, and as such provide an unrivalled experience in the launch of hundreds of companies around the world. With their experience and know-how, as well as a clear understanding of the specifications of the Ghana car market, they offer the best online market place for vehicles in Ghana. They are also the only market place that provides zero-fraud and trusted sellers with full transparency, thereby creating a premium experience (Anang, 2015). It is important, but unfortunate to know that transactions conducted within the environment of Carmudi.com.gh are through the use of physical cash, which is not as envisaged, within an e-business environment (Anang, 2015).

iii. Lamudi.com.gh helps people find their ideal home, land and commercial property. Its goal is to empower consumers with the most thorough information on the market and bring them in direct contact with the agents. Its listings aim to provide consumers with as much information as possible to gain an in-depth insight on each property. Lamudi.com.gh is setting the standard for providing a user-friendly, highly visual marketing platform for properties and land in Ghana (Anang, 2015). Lamudi.com.gh already has over 400 properties listed on their website from individuals and the largest agencies and developers, including Orel, Pelican Properties and Broll, Ghana. Lamudi.com.gh helps individuals find their perfect property and gives property owners an online presence. They are well integrated with various social media platforms, so individuals can save their favourite properties for Lamudi.com.gh accounts, and send them to friends and family over email, Facebook, Twitter and Google+ (Anang, 2015). Again, it is important, but unfortunate to know that transactions conducted within the environment of Lamudi.com.gh are through the use of physical cash, which is not as envisaged, within an e-business environment. 
iv. Kaymu.com.gh is one of the top online shopping communities in Ghana. It essentially connects buyers with sellers and vice-versa (Anang, 2015). Kaymu.com.gh believes that the internet can break economic barriers and change the way business is done. Therefore, the company brings e-commerce into the lives of Africans, to empower local entrepreneurs by helping them take their business online, and to make shopping easy and accessible to everyone (Anang, 2015).

Kaymu.com.gh was launched in December 2012 by Africa Internet Group, the e-commerce pioneers in Africa, and it is backed by Millicom, MTN and Rocket internet. Kaymu.com.gh has spread to over 32 countries across Africa, Asia and Europe, and with new countries being launched regularly (Anang, 2015).

v. Zoobashop.com is a Ghanaian-owned online retail site that offers a variety of electronics, home appliances, items of fashion, etc., and at decent prices. It currently delivers to all addresses in Accra and Tema (the capital twin-city), and expects to expand its delivery coverage in the not too distant future (Anang, 2015). Zoobashop.com allows several modes of payment, from the conventional cash-on-delivery to online credit / debit card payments, so paying for the things you buy is easy and convenient.

vi. Jumia.com.gh is essentially one of Africa's largest online shops for Fashion, Electronics, Home appliances and more ((Anang, 2015). The website offers a wide selection of products, including Men \& Women's Fashion, Mobile Phones, Computer Systems, Electronics, Home Appliances, etc. Furthermore, Jumia.com.gh brings items purchased right to customers' doorstep, according to Anang, 2015).

Apart from Ghana, Jumia.com is also available in Nigeria, Egypt, Morocco, Kenya and Ivory Coast.

Jumia,com.gh offers consumers with a wide selection of styles and brands, $100 \%$ convenience with 24/7 online access from a consumer's home or office, secured payment, such as Bank Deposit / Online banking and Cash on Delivery, exceptional customer care service, fast nextday delivery and returns after 7 days (Anang, 2015).

Jumia.com.gh is one of the few e-business sites in Ghana that create the environment for the establishment of buying and selling of items online, and are conducted through digital cash, as envisaged within an e-business environment ((Anang, 2015). However, all the online commerce shops in Ghana need robust / vigorous advertisement for their e-commerce activities to become known and popular to the Ghanaian populace, and the globe at large.

\section{READINESS OF GHANAIANS FOR E-COMMERCE}

Ghana's Interbank Payment and Settlement Systems (GhIPSS) has launched an internet payment gateway to enable holders of domestic Automated Teller Machine (ATM) cards to make payments and purchases online ((Anang, 2015). The launch of the 'gh-link e-commerce' is set to promote e-commerce and the creation of jobs, as various services are needed in the ecommerce value chain (Anang, 2015) to promote the efficient functioning of the e-commerce system.

It should be noted that Ghanaians are blessed to have almost all the banks in Ghana currently revamping and improving their online financial instruments, such as electronic visa cards (debit and credit). This is laudable, as these instruments of payment of purchases could now be relied upon for e-payment in e-commerce transactions.

Though Ghanaians have a long way to go, nevertheless, there is no gain saying that the nation is gradually warming itself into the online trading business, and poised to secure a lot of gains 
from this latest commerce / trading business. However, to fully get there, the banking system and the issuing of debit / credit cards should be extra-ordinarily secured from fraudsters.

A lot of awareness has been created on frauds within the banking system, where customers' card numbers may easily be stolen, and money subsequently, siphoned from such accounts (Stratcomm-Africa, 2019). The banks have a lot to do to help the nation to come out from the act of carrying large amount of physical cash for any small purchases one needs.

E-Commerce processes have experienced dramatic growth over the past decade and have become a key platform for organisations of all types and sizes. Theories of customer relationship management (CRM), enterprise resource planning (ERP), supply chain management (SCM), E-Commerce trust and loyalty have been developed for the transactional and relational components for effective communication, thereby impacting the customers' shopping experiences (Ratnasingam, 2008; Clarity-Ventures, 2019). E-commerce is a rapidly growing segment of the internet.

There are many reasons that may push one to conjecture that the cleaning of the banking sector by the current New Patriotic Party (NPP) government (Stratcomm-Africa, 2019) might have a lot to do with the emerging commerce trade, and the halt of carrying huge currency notes by Ghanaians for their purchases.

The nation has to make every effort to completely go electronic-cash so as to enjoy ecommerce transactions. The government has already done a lot to make this movement possible (Stratcomm-Africa, 2019). It is likely the coming days would experience more online activities, after Ghanaians have been encouraged by the government on the importance of transacting online business in Ghana.

\section{PERFORMANCE OF POPULAR GLOBAL E-BUSINESS SITES}

E-Business sites, such as eBay and Amazon have sales in billion USD and millions of active users. Example, Amazon posted 24\% increased revenue of $\$ 70 \mathrm{bn}$ for its 3rd quarter 2019 sales, up from $\$ 63.4 \mathrm{bn}$ in the preceding quarter (Statista, 2019).

The explosion of large-scale e-commerce by Amazon and eBay brings online individuals and organisations together to own and operate net-worked computer and application systems in order to maximize their own self-interests. It is the internet that has allowed Amazon and eBay to offer their products and services online to consumers, which is through web-based applications to customers. Effective retention of customers allows e-commerce companies to expand and increase their profitability (Ratnasingam, 2008), which has been the hallmark of Amazon and eBay.

\section{BENEFITS TO COMPANIES THAT GO E-COMMERCE}

Companies have utilized the internet and e-commerce in order to increase sales and reduce costs. With e-commerce, companies can web-enable their products and services. Transition to e-business solutions can be challenging and careful planning is always required.

Companies are utilizing online transactions not only to stabilize, but also to expand their market share in the global community. Thus companies are changing to e-business with the help of e-solutions providers; the providers sell complete services to help companies do their planning and accounting for online purchasing through interactions and transactions, using electronic format to fulfil customers' needs (Dbwebdoctor, 2020). 
Current literature reveals that it is NOT easy or cheap to switch to e-commerce because adding the internet and e-commerce would make a company undergo a metamorphosis of challenges in order to be able to have e-commerce revenues (Ngai \& Wat, 2002).

Finally, the advantages of e-commerce are many, as companies already there are utilizing online benefits to stabilize their businesses and expand market share in the global community. E-Commerce offers a plethora of advantages. These include, among others:

. reduction in the cost of communicating with customers;

. web-based opportunities for self-service activities;

. integration of services and production;

. possibly, increase of sales through the internet marketing;

. effective customer interaction with the firm;

. service improvements; and

. user-friendliness ((Dbwebdoctor, 2019).

Companies have utilized the internet and e-commerce to become globalized entities in order to increase sales and reduce costs. However, transition from brick-and-mortar (traditional) shop to e-business solutions could be challenging, and therefore, careful planning is always required. Literature has revealed that a company would undergo a metamorphosis of challenges, including initial heavy capital outlay in order to be able to have e-commerce revenues (Ratnasingam, 2008). However, when the clouds are settled over the challenges, the gains could be enormous to the organisation.

\section{CONCLUSION}

Ghanaians are indeed ready for a big take off into the online and e-commerce business, as the digital transformation being championed by the current government, NPP, in most areas of the economy, including the introduction of digital addressing system, is a testimony to the citizenry. Furthermore, the laying of Ghana's Interbank Payment and Settlement Systems (GhIPSS), an internet payment gateway to enable holders of domestic Automated Teller Machine (ATM) cards to make payments and purchases online ((Anang, 2015), is a clear manifestation of the intention of the government to move the nation to online business. Moreover, the sanitation of the Ghanaian banking system to remove quack banks from the banking environment (Stratcomm-Africa, 2019), is an indication that Ghana would soon be one of the best e-commerce and online business centres in Africa.

However, despite all the necessary online infrastructure laid by the government, if the populace do not avail themselves to fully embrace and utilize the online technological commerce, everything would come to naught. Much therefore, depend on Ghanaians and the business environment to make the digital transformation possible.

\section{References}

Al-Rawi, K., Sabry, K., \& Al-Nakeeb, A. (2008). Driving factors for E-commerce: Gulf Region Review. Academy of Information and Management Sciences Journal. 11(2).

Anang, T. (2015). Ghana's Top 12 e-commerce Websites. Retrieved from: https://www.itnewsafrica.com. January 2020.

Clarity-ventures (2019). B2B eCommerce, ERP \& CRM Integration. Retrieved from: https://www.clarityventures.com. January 2020.

Dbwebdoctor (2019). 10 Reasons why companies should start doing business online.

Retrieved from: https://www.dbwebdoctor.com. January, 2020.

Hendrieks, B. (2020). What is C2B? - Definition \& Examples. Retrieved from: https://www.study.com. January, 2020. 
Hom, E. J. (2013). Four categories of e-commerce. Retrieved from: https://www.businessnewsdaily.com. January, 2020.

Katzenbach, J. R., \& Smith, D. K. (2001). The Discipline of Virtual Teams, Leader to Leader. Retrieved from: https://doi.org/10.1002/ltl.

Merriam-webster (2020). Brick and mortar shops. Retrieved from: http://www.merriamwebster.com/dictionary/brick-and-mortar.

Ngai, E. W. T., \& Wat, F. K. T. (2002). A literature review and classification of electronic commerce research. Information \& Management Journal. 39 (2002) 415-429.

Ratnasingam, P. (2008). The Impact of E-Commerce Customer Relationship Management in Business-to-Consumer E-Commerce. Journal of Electronic Commerce in Organizations. 6(4), 30-46. October-December 2008.

Statista (2019). Amazon revenue for 2019. Retrieved from: https://www.statista.com.

Stratcomm-Africa (2019). Will Ghana's financial sector clean-up build a stronger banking system? Retrieved from: https://www.businessghana.com. January, 2020.

Wu, J. H., \& Hisa, T. L. (2008). Developing E-Business dynamic capabilities: an analysis of e-commerce innovation from I-, M-, to U-commerce. Journal of Organizational Computing and Electronic Commerce. 18: 95-111, 2008. ISSN: 1091-9392. 